\title{
Comparative Growth Response of Three Jatropha Species on Heavy Metal Contaminated Soil
}

\author{
Olamilekan L. Awotedu*, Paul O. Ogunbamowo, Bolajoko F. Awotedu, and Ileri-Oluwa B. Emmanuel \\ Forestry Research Institute of Nigeria, Jericho, Ibadan, Oyo State, Nigeria \\ * Corresponding author email: awotedulekan@gmail.com
}

Received: 27 March 2018 / Accepted: 23 May 2018 / Published: 24 May 2018

\begin{abstract}
This study investigated the comparative phytotoxcity effect of heavy metal contamination on Jatropha curcas, Jatropha gossypifolia and Jatropha multifida in contaminated soil from a dump site in Ibadan Nigeria. Seeds of J. curcas, J. gossypifolia and J. multifida were planted in a germination tray and later transplanted into polythene pots filled with $2 \mathrm{~kg}$ of either control soil or heavy metal contaminated soil, a $3 \times 2$ factorial experiment laid out in complete randomized design (CRD) replicated four times was adopted; treatments imposed include T1 - J. curcas/Control Soil, T2 - J. gossypifolia/Control Soil, T3 - J. multifida/Control Soil, T4 - J. curcas/Contaminated soil, T5 - J. gossypifolia/Contaminated Soil, and T6 - J. multifida/Contaminated Soil. Weekly variation in growth parameters: the plant height, leave production and stem diameter were measured over the course of 12 weeks. The growth parameters were dependent on a combination of both specie type and level of heavy metal contamination of soil. J. multifida (T3) $(36.93 \mathrm{~cm})$ performed best, comparable with J. gossypifolia (T2) $(34.1 \mathrm{~cm})$ after 12 weeks while J. multifida (T6) had the lowest mean plant height $(7.23 \mathrm{~cm})$ which is not significantly $(\mathrm{p}<0.05)$ different from other species on the contaminated soil; for leave production, J. gossypifolia (T2) produced the highest mean number of leaves (9.67) which is comparable with J. multifida (T3) (9.00) and less so with J. curcas (T1) (6.67) with significant leave losses on the contaminated soils after 12 weeks; variation in stem diameter shows that J. curcas (T1) had the highest stem girth (1.96 mm) which is comparable to the value obtained for J. curcas (T4) $(1.95 \mathrm{~mm})$, while J. multifida (T6) had the lowest stem girth (1.09 $\mathrm{mm}$ ). J. gossypifolia (T2) and J. multifida (T3) had comparable stem girth of $1.57 \mathrm{~mm}$ and $1.47 \mathrm{~mm}$ respectively. Toxicity of heavy metals in the contaminated soil greatly affect the growth parameters of the Jatropha.

Keywords: Growth Response, Heavy Metals, Jatropha curcas, Jatropha gossypifolia, Jatropha multifida, Phytotoxicity.
\end{abstract}

\section{Introduction}

The pollution of soil by Heavy metals is one of the most important environmental problems throughout the world which causes significant toxic effect on humans, animals, microorganisms and plants [1], [2]; contaminated soils and waters pose major environmental, agricultural and human health problems worldwide. Humans and the ecosystem may be exposed to chemical hazards such as heavy metals (lead, chromium, zinc, cadmium, copper, mercury and nickel) through the consumption of crops and vegetables grown on the contaminated lands or drinking water that has percolated through such soils [3]. Thus, the concern over this subject is on the survival of the plant on one hand and food safety risk on other hand where these plants may absorb some of these toxic metals into their tissues.

Jatropha species are used in traditional medicine to cure various ailments in Africa, Asia, and Latin America or as ornamental plants and energy crops and several known species from genus Jatropha have been reported for their medicinal uses, chemical constituents, and biological activities such as Jatropha curcas, Jatropha gossypifolia, and Jatropha multifida, among others [4]. 
J. curcas has been known to be a good phytoremediating plant capable of surviving in adverse heavy metal contamination, for instance, Idowu and Fayinminnu [5] investigated the phytotoxicity of spent oil contaminated soil on $J$. curcas, while several studies have also demonstrated its ability to withstand metal toxicities. Liang et al., [6] showed that J. curcas exhibited inherent tolerance to cadmium and lead stress and thus a good candidate for phytoremediation; the growth response of $J$. curcas to heavy metal contaminated sludge has been reported by several authors [7], [8], [9], [10] with various phytotoxic effects observed dependent on the level of heavy metals present in the growth media. However, little information is available on the phytotoxicity of heavy metal contaminated soil on other Jatropha species like J. gossypifolia and J. multifida growing abundantly in different parts of Nigeria. The research therefore aims at evaluating the comparative phytotoxcity effect of heavy metal contamination on J. curcas, J. gossypifolia and J. multifida with a view to find a common behavioural pattern in the Jatropha spps and consequently, an alternative Jatropha specie with phytoremediating potential.

\section{Materials and Methods}

The pot experiment was conducted within the premises of Forestry Research Institute of Nigeria, Ibadan which lies between $7 \circ 23^{\prime} \mathrm{N}$ and $3051 \mathrm{E}$ with an annual rainfall ranging from $1800 \mathrm{~mm}-2000 \mathrm{~mm}$ from January to March 2016. The Seeds of J. curcas, J. gossypifolia and J. multifida were obtained from the National Centre for Genetics Resources and Biotechnology (NACGRAB), Apata, Ibadan, identified and authenticated at the taxonomy section of Forestry Research Institute of Nigeria (FRIN), Ibadan, Oyo State. Contaminated soil (within a depth of $0-15 \mathrm{~cm}$ ) was collected randomly using a soil auger at the dumpsite located at Arapaja, Ibadan Oyo state $7 \circ 18^{\prime} \mathrm{N}$ and 3०50'E. This dumpsite has been in use since 1993. Contamination free soil (Control soil) was also collected within the premises of Forestry Research Institute of Nigeria, Ibadan. Portions of both contaminated and control soil samples were air dried for five (5) days, sieved using $2 \mathrm{~mm}$ mesh size and analysed for heavy metals specifically, lead, chromium, Nickel, Zinc and cadmium. This is to ascertain the level of contamination by the metals and thus the effect on the growth factors of the plants. Routine soil analysis was also done on the two soil samples using standard procedures described by [11].

Seeds of J. curcas, J. gossypifolia and J. multifida were planted into a germination tray and healthy seedlings of about $5 \mathrm{~cm}$ height were transplanted into each of polythene pots filled with $2 \mathrm{~kg}$ of either control soil or heavy metal contaminated soil from the dumpsite and labelled accordingly. A $3 \times 2$ factorial experiment laid out in complete randomized design (CRD) [12] [13], replicated four times given a total experimental unit of 24 was adopted; where the factors considered were Jatropha specie (curcas, multifida and gossypifolia) and the level of soil contamination. The treatments considered were:

T1 - J. curcas/Control Soil,

T2 - J. gossypifolia/Control Soil,

T3 - J. multifida/Control Soil,

T4 - J. curcas/Contaminated soil,

T5 - J. gossypifolia/Contaminated Soil,

T6 - J. multifida/Contaminated Soil

The control soil was considered uncontaminated in comparison to the soil collected from the dumpsite which is highly contaminated with heavy metals from the analysis of the soil heavy metal analysis before planting (Table 1). Watering was done daily and growth observed for twelve (12) weeks.

The effect of the heavy metals in the soil on the three Jatropha spp was studied by measuring the weekly variation in common growth parameters such as the plant height, leave production and stem diameter. The plant height of each seedling was measured with a measuring tape; leave production was assessed by counting the number of leaves produced per plant weekly and the stem diameter of each seedling per treatment was measured with use of vernier calliper weekly. The weekly data generated were subjected to Analysis of Variance and subsequently, Duncan Multiple Range test was used to separate mean where differences exist. SPSS version 20 was employed in the analysis of data. 


\section{Results}

Table 1 presents the pre-planting heavy metal concentration and Table 2 represents soil analysis for both the control soil and soil from the dump site. The various levels of heavy metals obtained in the soil samples from the dump site were significantly higher than the levels obtained at the control site indicating that the soil samples from the dump site is contaminated with heavy metals as the values were higher than the recommended standard except for Chromium and Nickel which are within the set standard. The heavy metal levels obtained for the control soil are within the recommended limit set by WHO/FAO.

Table 1: Heavy Metal Concentrations in Preplanting Control and Contaminated Soil

\begin{tabular}{|l|l|l|l|}
\hline $\begin{array}{l}\text { Metal } \\
(\mathrm{mg} / \mathrm{kg})\end{array}$ & $\begin{array}{l}\text { Control } \\
\text { soil }\end{array}$ & $\begin{array}{l}\text { Contaminated } \\
\text { soil }\end{array}$ & WHO/FAO \\
\hline $\mathrm{Cu}$ & 4.23 & 525.75 & 100 \\
\hline $\mathrm{Zn}$ & 32.00 & 1940.38 & 300 \\
\hline $\mathrm{Cr}$ & 2.63 & 25.63 & 100 \\
\hline $\mathrm{Cd}$ & 0.50 & 6.88 & 3.0 \\
\hline $\mathrm{Pb}$ & 6.00 & 325.15 & 100 \\
\hline $\mathrm{Ni}$ & 1.88 & 41.75 & 50 \\
\hline
\end{tabular}

Table 2: Pre-Planting Soil Analysis

\begin{tabular}{|l|l|l|}
\hline Soil parameter & Control & Contaminated \\
\hline pH & 6.9 & 7.77 \\
\hline Particle size & & \\
\hline Sand $(\%)$ & 85.80 & 86.20 \\
\hline Silt $(\%)$ & 8.80 & 10.40 \\
\hline Clay $(\%)$ & 5.40 & 3.40 \\
\hline Exchangeable bases & & \\
\hline Ca (cmol) & 14.01 & 60.75 \\
\hline Mg (cmol) & 2.51 & 2.63 \\
\hline K (cmol) & 0.44 & 7.92 \\
\hline Na (cmol) & 0.98 & 14.54 \\
\hline & & \\
\hline Al+H (cmol) & 0.06 & 0.05 \\
\hline ECEC (cmol) & 17.77 & 85.89 \\
\hline Base saturation $(\%)$ & 99.67 & 99.94 \\
\hline Total Nitrogen (\%) & 0.09 & 0.21 \\
\hline $\begin{array}{l}\text { Total Organic Carbon } \\
(\%)\end{array}$ & 0.89 & 3.38 \\
\hline Av. P P (mg/kg) & 12.31 & 16.70 \\
\hline Micro-nutrients & \multicolumn{2}{|l|}{} \\
\hline Mn (mg/kg) & 66.62 & 53.15 \\
\hline Fe (mg/kg) & 39.42 & 17.65 \\
\hline Cu (mg/kg) & 1.07 & 1.10 \\
\hline Zn (mg/kg) & 7.15 & 1.20 \\
\hline & & \\
\hline
\end{tabular}

The weekly variation in plant height over the course of 12 weeks after transplanting is shown in Figure 1. The growth response in terms of plant height was dependent on a combination of both the specie type and the level of heavy metal contamination of soil after 12 weeks as observed in the analysis of variance (Table 3). Comparable growth rate in terms of plant height was observed in the first 4 weeks after planting; however, the control plants significantly $(p<0.05)$ fared better in plant heights compared to the plants grown on the contaminated soil with the J. multifida performing best on the control soil (T3) with a height of $36.93 \mathrm{~cm}$ which is comparable with $J$. gossypifolia $(34.1 \mathrm{~cm})$ (T2) after 12 weeks while $J$. multifida planted on the contaminated soil (T6) had the lowest mean plant height of $7.23 \mathrm{~cm}$ which is not significantly different from other species planted on the contaminated soil.

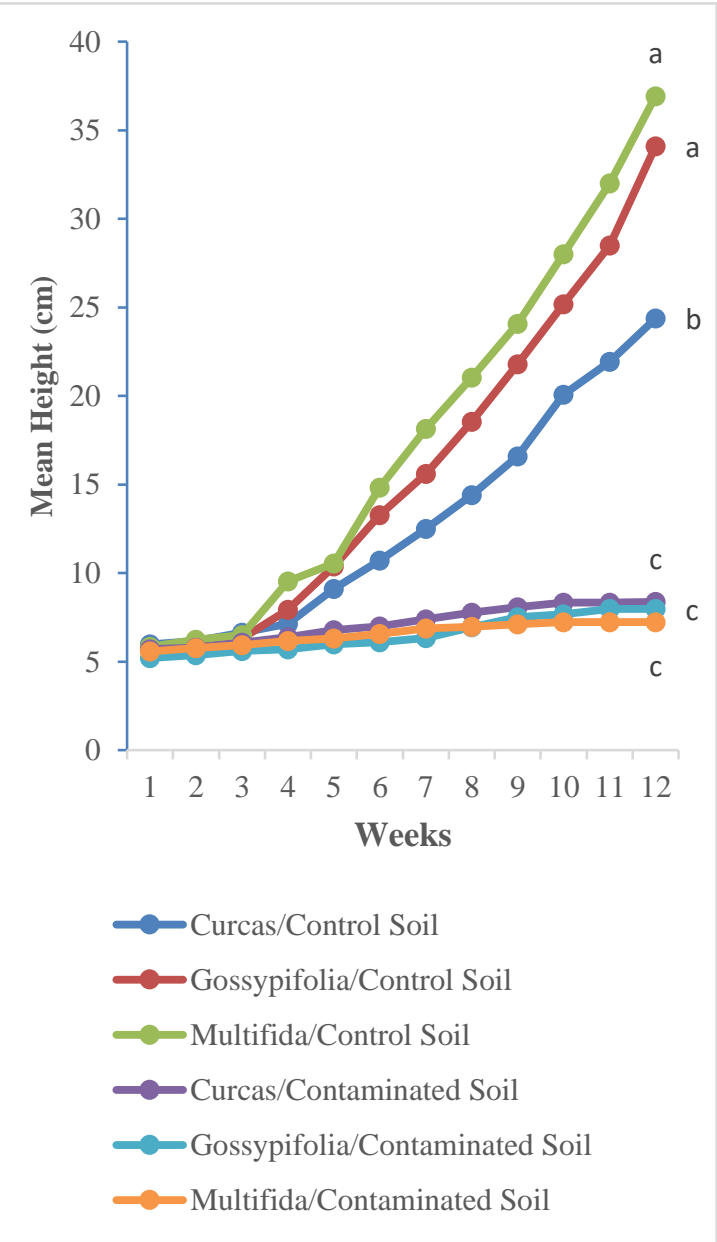

Figure 1: Variation in Mean Plant Heights Across 12 Weeks. Mean with the same alphabets are not significantly different at $P<0.05$ 
Comparative Growth Response of Three Jatropha Species on Heavy Metal Contaminated Soil

Table 3: Analysis of Variance Tests of BetweenSubjects Effects Plant Height After Week 12

\begin{tabular}{|l|l|l|l|l|l|}
\hline Source & $\begin{array}{l}\text { Type III } \\
\text { Sum of } \\
\text { Squares }\end{array}$ & df & $\begin{array}{l}\text { Mean } \\
\text { Square }\end{array}$ & F & Sig. \\
\hline $\begin{array}{l}\text { Corrected } \\
\text { Model }\end{array}$ & $3789.875^{\mathrm{a}}$ & 5 & 757.975 & 539804.115 & .000 \\
\hline Intercept & 9435.511 & 1 & 9435.511 & 6719651.540 & .000 \\
\hline Jatropha specie & 147.844 & 2 & 73.922 & 52644.715 & .000 \\
\hline $\begin{array}{l}\text { Contamination } \\
\text { level }\end{array}$ & 3439.939 & 1 & 3439.939 & 2449807.979 & .000 \\
\hline $\begin{array}{l}\text { Jatropha } \\
\text { specie* } \\
\text { Contamination } \\
\text { level }\end{array}$ & 202.092 & 2 & 101.046 & 71961.582 & .000 \\
\hline Error & .025 & 18 & .001 & & \\
\hline $\begin{array}{l}\text { Total } \\
\text { Corrected }\end{array}$ & 3789.900 & 23 & & & \\
\hline Total & 3711 & 24 & & & \\
\hline
\end{tabular}

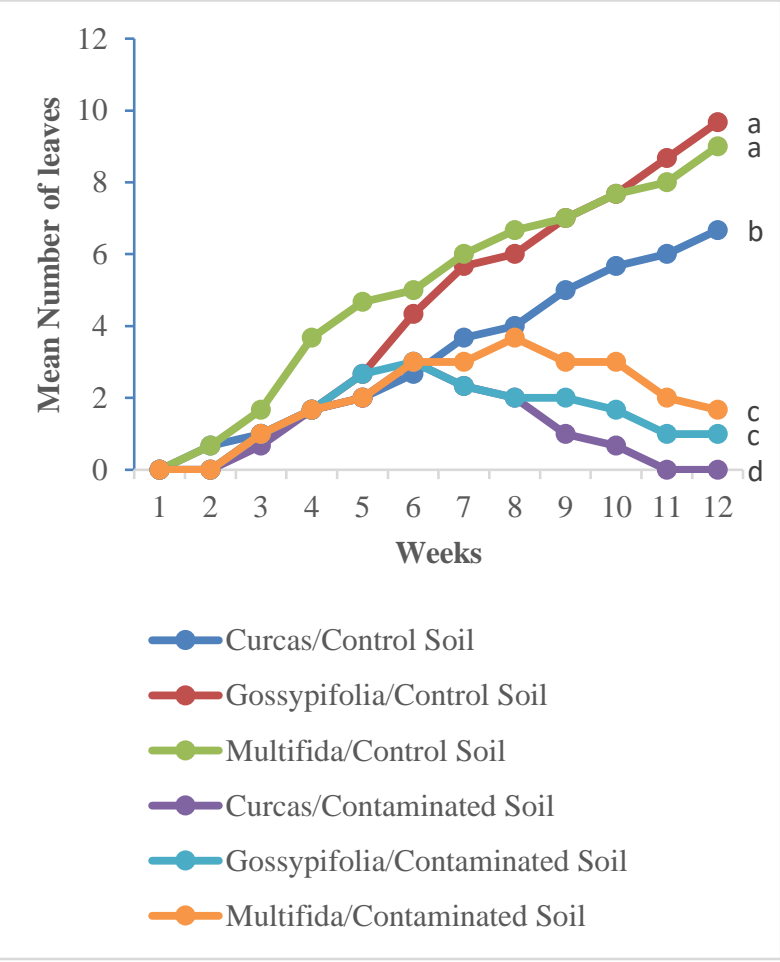

Figure 2: Variation in Mean Leaf Production Across 12 Weeks. Mean with the same alphabets are not significantly different at $P<0.05$

The weekly variation in mean number of leaves produced over the course of 12 weeks is presented in Figure 2. As in the case of plant height, an interaction effect of Jatropha spp and the contamination level of soil was observed which suggests that the growth response in terms of number of leaves is also dependent on a combination of both the specie type and the level of heavy metal contamination of soil after 12 weeks (Table 4).
Table 4: Analysis of Variance Tests of Between-

Subjects Effects Number of Leaves after Week 12

\begin{tabular}{|l|l|l|l|l|l|}
\hline Source & $\begin{array}{l}\text { Type III } \\
\text { Sum of } \\
\text { Squares }\end{array}$ & df & $\begin{array}{l}\text { Mean } \\
\text { Square }\end{array}$ & F & Sig. \\
\hline Corrected Model & $358.691^{\mathrm{a}}$ & 5 & 71.738 & 182.815 & .000 \\
\hline Intercept & 495.305 & 1 & 495.305 & 1262.219 & .000 \\
\hline Jatropha specie & 20.770 & 2 & 10.385 & 26.465 & .000 \\
\hline $\begin{array}{l}\text { Contamination } \\
\text { Level }\end{array}$ & 324.611 & 1 & 324.611 & 827.226 & .000 \\
\hline $\begin{array}{l}\text { Jatropha specie * } \\
\text { Contamination } \\
\text { Level }\end{array}$ & 4.125 & 2 & 2.063 & 5.256 & .017 \\
\hline Error & 6.671 & 17 & .392 & & \\
\hline Total & 894.802 & 23 & & & \\
\hline Corrected Total & 365.362 & 22 & & \\
\hline \multicolumn{5}{|l|}{ a. R Squared $=.982$ (Adjusted R Squared = .976) } \\
\hline
\end{tabular}

Leaf production within the first three weeks was muted and comparable across all treatments however, J. gossypifolia planted on the control soil (T2) produced the highest mean number of leaves after 12 weeks which is comparable with $J$. multifida on control soil (T3) and less so with $J$. curcas on control soil (T1) at $\mathrm{p}<0.05$; however, leave production by all the species was greatly reduced after 12 weeks on the contaminated soil with J. curcas (T4) shedding all its leaves after 12 weeks.
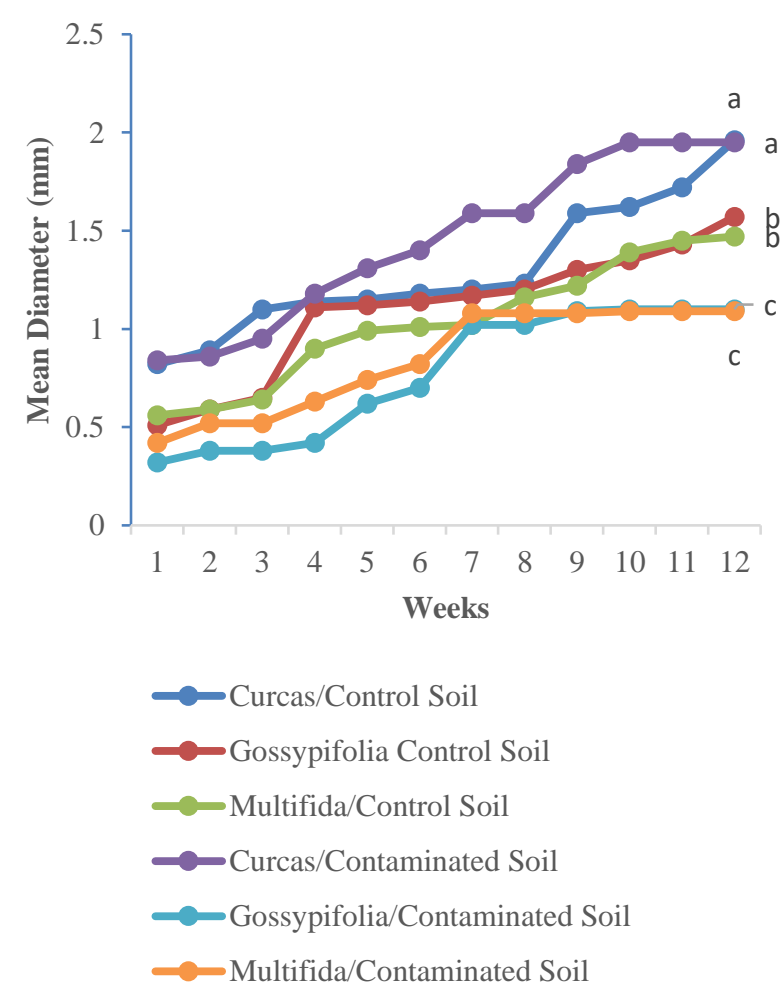

Figure 3: Variation in Mean Stem Diameter Across 12 Weeks. Mean with the same alphabets are not significantly different at $P<0.05$ 
Awotedu et al., Int. Ann. Sci.; Vol. 5, Issue 1, pp: 26-32, 2018

Figure 3 presents the weekly variation in mean stem girth produced over the course of 12 weeks. A significant $(p<0.05)$ interaction effect between the Jatropha specie type and heavy metal contamination was also observed (Table 5), which also suggests that the stem girth is dependent on a combination of both the specie type and the level of contamination. The result shows that $J$. curcas planted on the control soil (T1) had the highest stem girth of $1.96 \mathrm{~mm}$ which is comparable to the value obtained for J. curcas grown on the contaminated soil (T4), while $J$. multifida grown on the contaminated soil (T6) had the lowest stem girth of $1.09 \mathrm{~mm}$. J. gossypifolia (T2) and J. multifida (T3) planted on control soil had comparable stem girth of $1.57 \mathrm{~mm}$ and $1.47 \mathrm{~mm}$ respectively.

Table 5: Analysis of Variance Tests of BetweenSubjects Effects Stem Diameter after Week 12

\begin{tabular}{|l|l|l|l|l|l|}
\hline Source & $\begin{array}{l}\text { Type } \\
\text { III Sum } \\
\text { of } \\
\text { Squares }\end{array}$ & df & $\begin{array}{l}\text { Mean } \\
\text { Square }\end{array}$ & F & Sig. \\
\hline $\begin{array}{l}\text { Corrected } \\
\text { Model }\end{array}$ & $2.979^{\mathrm{a}}$ & 5 & .596 & 1165.670 & .000 \\
\hline $\begin{array}{l}\text { Intercept } \\
\text { Jatropha } \\
\text { specie }\end{array}$ & 55.693 & 1 & 55.693 & 108964.696 & .000 \\
\hline $\begin{array}{l}\text { Contamination } \\
\text { level }\end{array}$ & .493 & 1 & .493 & 964.696 & .000 \\
\hline $\begin{array}{l}\text { Jatropha } \\
\text { specie } \\
\text { Contamination } \\
\text { level }\end{array}$ & .238 & 2 & .119 & 232.565 & .000 \\
\hline Error & .009 & 18 & .001 & & \\
\hline Total & 58.681 & 24 & & & \\
\hline $\begin{array}{l}\text { Corrected } \\
\text { Total }\end{array}$ & 2.988 & 23 & & & \\
\hline \multicolumn{2}{|c|}{ R Squared = } & & & & \\
\hline
\end{tabular}

\section{Discussion}

The three growth parameters measured in this study were plant height, stem girth and number of leaves for each Jatropha spp in both the control and contaminated soil. The analysis of variance shows that there was significant difference $(\mathrm{P}<$ 0.05) in plant height, stem girth and number of leaves of the Jatropha spp planted in the control and contaminated soil in the twelve (12) weeks of study. This indicated that the growth performance of the Jatropha spp studied were dependent on a combination of both the specie type and level of contamination. The growths of the Jatropha spp in terms of plant height were found to be greatly reduced in the contaminated soil when compared to that observed in the control soil. The highest mean plant height $(36.93 \mathrm{~cm})$ recorded in the $J$. multifida grown on the control soil (T3) is comparable to that of $J$. gossypifolia $(34.1 \mathrm{~cm})$ grown on the control soil (T2) and significantly higher than J. curcas grown on the control soil (T1). However, J. curcas grown in the contaminated soil (T4) had the highest mean plant height of $(8.37 \mathrm{~cm})$ which is not significantly different from J. gossypifolia (T5) and J. multifida (T6) which are $(7.97 \mathrm{~cm})$ and $(7.23 \mathrm{~cm})$ respectively. This result is comparable to that reported by Ahmadpour et al., [7] who reported a range of $6.98 \mathrm{~cm}-8.79 \mathrm{~cm}$ for J. curcas cultivated on various mixtures of soil and heavy metal contaminated sewage sludge. The implication of this is that toxicity of heavy metal in the contaminated soil greatly affected the growth of the Jatropha irrespective of the specie however, J. multifida and J. gossypifolia performed better than J. curcas on the control soil. The growth of the Jatropha spp was found to be slow in the first few weeks of transplanting in both control and contaminated soils, which likely occurred due to the plants attempting to acclimatize themselves to the new growing medium. The weekly trend in plant height also shows a retarded growth rate over the course of the last three weeks in the contaminated soil; a trend similarly observed by Majid et al., [8] and is attributed to the higher concentration of heavy metals in the soil which may have disrupted the ability of the plant to make use of the necessary nutrients for growth in the soil.

In the production of leaves similar trend as in plant height was observed; J. gossypifolia grown on the control soil (T2) produced the highest mean number of leaves (9.67) after twelve (12) weeks which is comparable $(\mathrm{p}<0.05)$ to the mean number of leaves (9.00) produced by J. multifida (T3) after same period. The Jatropha spp planted on the contaminated soil however paled significantly in the number of leaves when compared to those of the control soil (Figure 2). This further highlighted the significant effect of heavy metal toxicity in the soil on all the Jatropha species used in this study because at the end of twelve (12) weeks, there was $100 \%$ decrease in 
the number of leaves of $J$. curcas planted on the contaminated soil contrary to $40-60 \%$ decrease observed by Luhach and Chaudhry, [9]. The reason for this difference may be due to the fact that in the latter's study, various ratios of heavy metal contaminated sewage sludge was used which may provide lower level of heavy metal contamination in some of the treatments compared to the grossly contaminated soil sample used in this study. However, J. gossypifolia and J. multifida maintained similar level of leave decrease observed by Luhach and Chaudhry, [9] in J. curcas. This trend of lower number of leaves over time in the Jatropha plants grown on the contaminated soil was also reported by Ahmadpour et al., [7] for J. curcas.

In the stem diameter, J. curcas grown on the control soil (T1) had the highest mean stem girth of $1.96 \mathrm{~mm}$ which is not significantly different from $1.95 \mathrm{~mm}$ measured for J. curcas grown on the contaminated soil (T4) after twelve (12) weeks, while J. gossypifolia (T5) and J. multifida (T6) grown on the contaminated soil have comparatively smaller value of stem girth after twelve weeks (Figure 3). Ahmadpour et al., [7] reported a high stem diameter for J. curcas cultivated on a combination of $80 \%$ heavy metal contaminated sludge and $20 \%$ soil, this is quite similar to that observed in this study for J. curcas cultivated on the contaminated soil which is significantly higher than the other Jatropha species in the contaminated soil, this however, is in contrast to the trend reported by Majid et al., [8] where stem girth was reduced as a result of contamination. Here, a variation in specie performance in different contamination level is highlighted with J. curcas having comparable stem diameter in both control and contaminated soil which is different from the other species. The stem girth however, remains retarded around the last three (3) weeks. The growth parameters of Jatropha spp were affected more or less by the toxicity of the contaminated soil and the multimetal contamination on it, thus, higher level of contamination decreased the growth parameters to great extent. There may however be the potential of the Jatropha spp to withstand the toxicities in the long term as findings in the study by Juwarkar et al., [14] suggests that J. curcas long term survival in heavy metal contaminated soils may be promoted after amendment with soil improving organic waste materials.

\section{Conclusion}

This study has demonstrated the phytotoxicity of soil from dumpsite due to heavy metal contamination on the three Jatropha species studied. J. gossypifolia and multifida gave comparable growth response which is better than Jatropha curcas grown on control soil. Jatropha spp grown on heavy metal contaminated soil generally showed retarded growth rate compared to those planted on the non-contaminated soil. All the species had comparable growth parameters after twelve weeks on the contaminated soil which highlighted the adverse effect of heavy metal pollution in the soil on the plants. While J. curcas maintained similar level of stem girth in the contaminated soil as those cultivated on the control soil with total loss of leaves at the end of twelve weeks, J. gossypifolia and J. multifida were still able to retain some of their leaves thus indicating the specie variation effect which shows that each of the Jatropha spp has its different ways of responding to heavy metal toxicity and this therefore confirms that the phytotoxicity of soil, or wastes with higher concentrations of contaminants, may inhibit plant growth. This limitation could however be alleviated by the use of soil amendments that will improve the survival of these species on grossly contaminated soil and potentially serve as phytoremediators.

\section{How to Cite this Article:}

O. Awotedu, P. Ogunbamowo, B. Awotedu, and I.-O. Emmanuel, "Comparative Growth Response of Three Jatropha Species on Heavy Metal Contaminated Soil", International Annals of Science, vol. 5, no. 1, pp. 26-32, May 2018. doi:10.21467/ias.5.1.26-32

\section{References}

[1] J. Singh and A. S. Kalamdhad, "Effects of heavy metals on soil, plants, human and aquatic life," International Journal of Research in Chemistry and Environment, vol.1, no. 2, pp. 15-21, 2011.

[2] A. S. Ayangbenro and O. O. Babalola, "A new stragegy for heavy metal polluted environments: a review of microbial biosorbents," International Journal of Environmental Research and Public Health. Vol. 14 (1), no. 94, 2017. 
[3] M. J. McLaughlin, B. A. Zarcinas, D. P. Stevens, and N. Cook, "Soil testing for heavy metals," Commun. Soil Sci. Plant Anal., vol. 31, no. 11-14, pp. 1661-1700, 2000.

[4] C. W. Sabandar, N. Ahmat, F. M. Jaafar, and I. Sahidin, "Medicinal property, phytochemistry and pharmacology of several Jatropha species (Euphorbiaceae): a review," Phytochemistry, vol. 85, pp. 7-29, 2013.

[5] O. D. Idowu and O. O. Fayinminnu, "Phytotoxicity Effect of Spent Oil on Jatropha curcas Seedlings Used in Soil Phytoremediation," Ethiopian Journal of Environmental Studies \& Management, vol. 8 no. Suppli. 2, pp. 906-915, 2015.

[6] J. Z. Liang, L. Yang, Y. Tang, Xu S. Wang and F. Chen, "Growth performance and tolerance responses of jatropha (Jatropha curcas) seedling subjected to isolated or combined cadmium and lead stresses," Int. J. Agric. Biol., vol. 14, pp. 861-869, 2012.

[7] P. Ahmadpour, A. M. Nawi, A. Abdu, H. Abdul-Hamid, D. K. Singh, A. Hassan, N. M. Majid, and S. Jusop, "Uptake of heavy metals by Jatropha curcas L. planted in Soils Containing Sewage Sludge," American Journal of Applied Sciences. Vol. 7, no. 10, pp. 1291-1299, 2010.

[8] N. M. Majid, M. M. Islam, and R. Riasmi, "Heavy metal uptake and translocation by Jatropha curcas L. in sawdust sludge contaminated soils," Australian Journal of Crop Science, vol. 6 no. 5, pp. 891-898, 2012.

[9] J. Luhach and S. Chaudhry, "Phytoremediation potential of Jatropha curcas for removal of heavy metals from refinery sludge," Int J Sci Eng Res, vol. 3, pp. 1-5, 2012.

[10] G. Maryam, N. M. Majid, M. M. Islam, O. H. Ahmed, and, A. Abdu, "Phytoremediation of coppercontaminated sewage sludge by tropical plants," Journal of Tropical Forest Science, vol. 27, no. 4, pp. 535-547, 2015.

[11] J. B. Jones, "Soil analysis handbook of reference methods," CRC Press Boca Raton, London, New York, Washington D. C. 1999.

[12] M. Rahimi, M. R. A. Poor, R. Farhadi, and A. Bagherifard, "Effects of potassium and phosphorus fertilizers on arsenic phytotoxicity and essential oil yield of two basil cultivars. Bulletin of Environment, Pharmacology and Life Sciences, vol. 2, no. 5, pp. 8692, 2013.

[13] R. Kazemi, N. Karimian, A. Ronaghi, and J. Yasrebi, "The effect of two humic substances on the growth and lead uptake of corn in calcareous soil," Iran Agricultural Research, vol. 35, no. 1, pp. 39-48, 2016.

[14] A. A. Juwarkar, S. K. Yadav, P. Kumar, and S. K. Singh, "Effect of biosludge and biofertilizer amendment on growth of Jatropha curcas in heavy metal contaminated soils Environ Monit Assess vol. 145, pp. 7-15, 2008.

\section{Publish your research article in AIJR journals-}

$\checkmark$ Online Submission and Tracking

$\checkmark$ Peer-Reviewed

$\checkmark$ Rapid decision

$\checkmark$ Immediate Publication after acceptance

$\checkmark \quad$ Articles freely available online

$\checkmark \quad$ Retain full copyright of your article.

Submit your article at journals.aijr.in

Publish your books with AIJR publisher-

$\checkmark$ Publish with ISBN and DOI.

$\checkmark$ Publish Thesis/Dissertation as Monograph.

$\checkmark$ Publish Book Monograph.

$\checkmark$ Publish Edited Volume/ Book.

$\checkmark$ Publish Conference Proceedings

$\checkmark \quad$ Retain full copyright of your books.

Submit your manuscript at books.aijr.org 